\title{
ANALYSIS OF THE FACTORS AFFECTING THE ADOPTION OF ORGANIC FARMING IN TURKEY: THE CASE OF SAMSUN PROVINCE
}

\author{
CUKUR, T. $^{1 *}-$ KizILASLAN, N. ${ }^{2}-$ KizILASLAN, $\mathrm{H}^{2}$ \\ ${ }^{I}$ Department of Marketing and Advertising, Milas Vocational School, Muğla Sitkı Koçman \\ University, Milas, Muğla, Turkey \\ ${ }^{2}$ Department of Agricultural Economics, Agricultural Faculty, Tokat Gaziosmanpaşa \\ University, Tokat, Turkey \\ *Corresponding author \\ e-mail: tayfun.cukur@hotmail.com; phone: +90-252-211-3263; fax: +90-252-211-1879
}

(Received 24 $4^{\text {th }}$ May 2019; accepted $3^{\text {rd }}$ Sep 2019)

\begin{abstract}
Organic farming is an environmentally friendly agricultural system which is very important in terms of the environment, human and plant and animal health. Thanks to organic farming, soil and water resources and air are protected from excessive contamination. In this respect, organic farming also contributes to the sustainable use of natural resources. Seen from this perspective, the adoption and application of organic farming by farmers is very important. This research was conducted to determine the factors affecting the adoption of organic farming by farmers. The study was executed in the Bafra district of Samsun province in Turkey. Within the context of the study, face-to-face administration of a questionnaire to a total of 54 farmers from nine different villages was performed. The proportional sampling method was used to determine the number of producers to be surveyed. It was determined that the most important factors are the health factors for farmers to adopt organic farming. They are followed by environmental protection factors, economic factors, social factors and innovativeness factors. All the farmers participating in the current study were determined to want to go on with organic farming in the future.
\end{abstract}

Keywords: farmers' preference, organic agriculture, conversion, adoption, environment

\section{Introduction}

The history of organic farming dates back to the 1940s, first each country started its development in itself and then its structure and trade developed worldwide. The first worldwide organization was founded in 1972 with the establishment of International Federation of Organic Agriculture Movements (IFOAM). World trade began to develop in the late 1970s and reached the market size in the 1980s (Altındişli and Aksoy, 2010). Organic farming is an alternative production method that aims to improve not only the quantity but also the quality of production and includes human and environmentally friendly production systems for reestablishing the natural equilibrium which is lost as a result of faulty practices in the ecological system, and prohibits the use of synthetic chemical pesticides, hormones and mineral fertilizers while recommending the use of organic and green fertilization and alternation (Aksoy and Altındişli, 1999).

Organic farming started in Turkey in 1984-85 with the demand of European companies for the production of traditional products such as dried fruits and nuts organically (Aksoy, 2002). The organic farming model generally implemented in Turkey is carried out in the form of contract farming between companies and organic producers. According to these contracts, the producers stipulate not to use synthetic fertilizers and pesticides in line with the direction of the project managers of the organic 
companies and carry out other necessary agricultural practices (use of organic inputs and agricultural methods) (Demiryürek, 2011).

In 2018, the number of farmers engaged in organic plant production was 54666. The total area of organic farming was 365889.54 hectare. When organic animal production data for the year 2018 was analyzed, it was found that a total of 148 farmers raise organic animals. When the data for the organic beekeeping were examined, it was found that 334 farmers were in the business of organic beekeeping and the number of hives under such conditions was 51742 (Anonymous, 2019a).

Organic farming started in Samsun province in 1994 with the production of organic hazelnuts. The use of pesticides and chemical fertilizers in areas other than Bafra and Çarşamba plains is quite low. In this respect, Samsun has an important potential for organic farming. In 2018, the number of farmers engaged in organic crop farming in Samsun province was 1013. The total area of organic farming was 3343.65 hectare (Anonymous, 2019a). In the current study, it was aimed to reveal the process of adoption of organic farming and the factor affecting this process in the Bafra district of the Samsun province.

\section{Materials and methods}

The main material of the current study is made up of the data collected by means of face-to-face administration of a questionnaire to a total of 54 producers engaged in organic farming in the villages of Çalköy, Darboğaz, Dikencik, Elifli, İkizpınar, Köseli, Ozan, Sürmeli and Uluağaç in the Bafra district of the Samsun province in Turkey (Fig. 1). Moreover, previous research on organic farming has also been capitalized on.

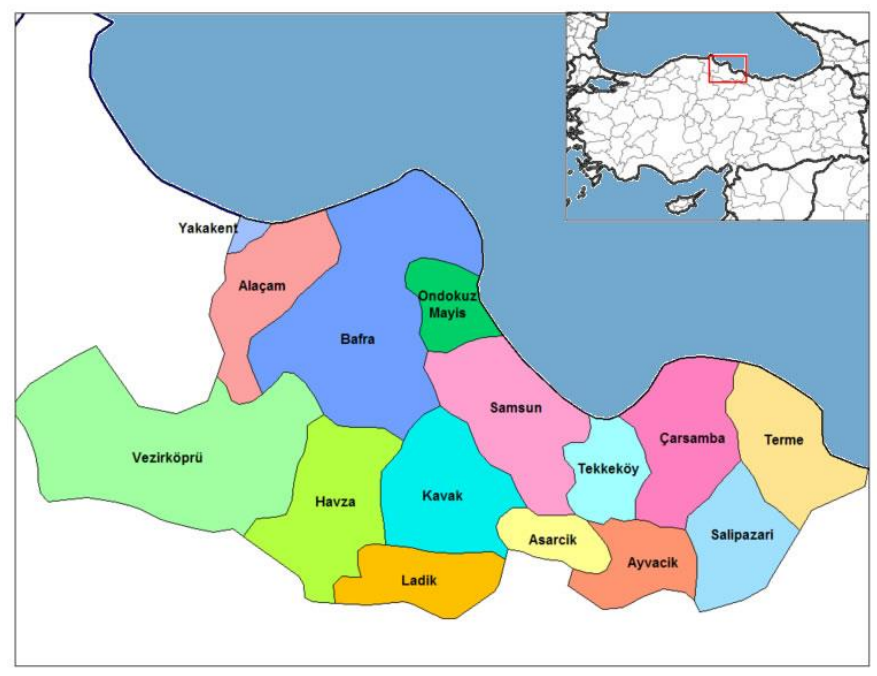

Figure 1. Map of Samsun Province. (Source: Anonymous, 2019b)

The questionnaire consists of four parts. These parts are; socio-economic features of the producers, general features of the agricultural enterprises, the farmers' state of plant production and the farmers' state of organic production. The questionnaires were administered in February and March, 2017. 
After the research data had been collected, the analysis process was initiated. In the analysis of the collected data, means and frequencies were calculated. Moreover, in order to determine the farmers' attitudes towards organic farming, a five-point Likert scale was used. The obtained results are summarized in tables and then interpreted and evaluated.

\section{Results}

\section{Socio-economic features of the farmers}

Within the context of the socio-economic features, the farmers' age, gender, education level, the number of people in the family, income sources, income level and their membership to any agricultural association were investigated in the current study. Of the participating farmers, $92.59 \%$ are males and $7.41 \%$ are females. The mean age of the participating farmers was found to be 59.54. When the education levels of the farmers were examined, it was found that $53.70 \%$ are elementary school graduates, $16.67 \%$ are middle school graduates, $12.96 \%$ are high school graduates, $11.11 \%$ are university graduates, $3.70 \%$ are literate and $1.86 \%$ are illiterate. The mean number of members in the family was found to be 5.15 .

It was determined that $87.04 \%$ of the farmers do not keep their business records regularly. All the farmers participating in the current study were found to be a member to an agricultural association. When the agricultural associations subscribed were examined, it was found that all of them are members to the Chamber of Agriculture.

It was also found that the participating farmers are engaged in the production of many organic products. These products include nuts, walnuts, wheat, corn, eggplant, peppers, apples, strawberries, tomatoes, cucumbers and beans. The production areas of these products are as follows: Nut 20.67 decares, walnut 13.30 decares, wheat 3 decares, corn 10 decares, eggplant 2 decares, pepper 2 decares, apple 5.50 decares, strawberry 3 decares, tomato 2 decares, cucumber 3.67 decares, bean 1.37 decares.

\section{Some characteristics of the farms investigated}

The farms investigated were found to have 45.06 decares arable land on average and the number of average parcels was calculated to be 6.56. In the current research, it was determined that all of the farmers perform their agricultural activities on the property land. Besides, it was determined that $11.11 \%$ of the farmers conduct their agricultural activities on the rented land and that only one producer conducts his/her agricultural activities in the jointly operated land. In the current research, it was also found that $11.11 \%$ of the farmers are also engaged in animal breeding.

In the current research, $79.63 \%$ of the farmers were found to have non-agricultural income sources. The farmers were asked the question "How is your income level compared to other farmers in your village?" Majority of the farmers $(77.78 \%)$ were found to be in the middle income group, $14.81 \%$ were found to be in the low income group and $7.41 \%$ were found to be in the high income group.

\section{Findings related to organic farming}

When how the farmers were first introduced to the concept of organic farming was examined, it was found that $57.41 \%$ of them first heard of the concept of organic farming from agricultural associations, $12.96 \%$ from universities, $11.11 \%$ from 
television and radio, $9.26 \%$ from books/journals/newspapers, $5.56 \%$ from friends and relatives and $3.70 \%$ from pioneering farmers. When the farmers were asked the question "How long time passed between your first introduction to the concept of organic farming and your starting organic farming?", $66.67 \%$ stated that they immediately started, $24.07 \%$ stated that they started 1 to 5 years later and $9.26 \%$ stated that they started after 5 years had passed. When how long the farmers had been in the business of organic farming was investigated, it was found that $92.59 \%$ had been in the business of organic farming for $0-5$ years, $5.56 \%$ had been in the business of organic farming for $6-10$ years and $1.85 \%$ for $11-20$ years.

In the current study, it was determined that the most effective factors on the adoption of organic farming by the farmers are health factors. They are followed by environmental protection factors, economic factors, social factors and innovativeness factors (Table 1).

Table 1. Factors affecting the adoption of organic farming

\begin{tabular}{c|c|c|c|c|c|c|c|c|c|c|c}
\hline \multirow{2}{*}{} & $\begin{array}{c}\text { Not effective } \\
\text { at all }\end{array}$ & \multicolumn{2}{|c|}{$\begin{array}{c}\text { Little } \\
\text { effective }\end{array}$} & \multicolumn{2}{c|}{ Effective } & \multicolumn{2}{c|}{$\begin{array}{c}\text { Very } \\
\text { effective }\end{array}$} & $\begin{array}{c}\text { Extremely } \\
\text { effective }\end{array}$ & $\begin{array}{l}\text { Scale } \\
\text { mean }\end{array}$ \\
\cline { 2 - 13 } & $\mathbf{n}$ & $\mathbf{\%}$ & $\mathbf{n}$ & $\mathbf{\%}$ & $\mathbf{n}$ & $\mathbf{\%}$ & $\mathbf{n}$ & $\mathbf{\%}$ & $\mathbf{n}$ & $\boldsymbol{\%}$ & \\
\hline Environmental protection factors & 0 & 0.00 & 0 & 0.00 & 1 & 1.85 & 38 & 70.37 & 15 & 27.78 & 4.26 \\
Innovativeness factors & 0 & 0.00 & 53 & 98.15 & 1 & 1.85 & 0 & 0.00 & 0 & 0.00 & 2.02 \\
Economic factors & 0 & 0.00 & 27 & 50.00 & 26 & 48.15 & 1 & 1.85 & 0 & 0.00 & 2.52 \\
Social factors & 0 & 0.00 & 28 & 51.85 & 25 & 46.30 & 1 & 1.85 & 0 & 0.00 & 2.50 \\
Health factors & 0 & 0.00 & 0 & 0.00 & 1 & 1.85 & 14 & 25.93 & 39 & 72.22 & 4.70 \\
\hline
\end{tabular}

The percentage of the farmers thinking that organic farming does not any effect on the income level was found to be 77.78 . While $11.11 \%$ of the farmers stated that organic farming has an income increasing effect, $11.11 \%$ stated that it has an income decreasing effect.

The primary purpose why the farmers are engaged in organic production is to produce healthy products (Table 2 ).

Table 2. The purpose why the farmers are engaged in organic production

\begin{tabular}{c|c|c|c|c|c|c|c|c|c|c|c}
\hline & \multicolumn{2}{|c|}{$\begin{array}{c}\text { Not effective } \\
\text { at all }\end{array}$} & \multicolumn{2}{c|}{$\begin{array}{c}\text { Little } \\
\text { effective }\end{array}$} & \multicolumn{2}{|c|}{ Effective } & \multicolumn{2}{c|}{$\begin{array}{c}\text { Very } \\
\text { effective }\end{array}$} & \multicolumn{2}{c|}{$\begin{array}{c}\text { Extremely } \\
\text { effective }\end{array}$} & $\begin{array}{c}\text { Scale } \\
\text { mean }\end{array}$ \\
\cline { 2 - 11 } & $\mathbf{n}$ & $\mathbf{\%}$ & $\mathbf{n}$ & $\mathbf{\%}$ & $\mathbf{n}$ & $\mathbf{\%}$ & $\mathbf{n}$ & $\mathbf{\%}$ & $\mathbf{n}$ & $\mathbf{\%}$ & \\
\hline $\begin{array}{c}\text { Producing healthy } \\
\text { products }\end{array}$ & 0 & 0.00 & 0 & 0.00 & 0 & 0.00 & 5 & 9.26 & 49 & 90.74 & 4.91 \\
$\begin{array}{c}\text { Environmentally } \\
\text { sensitive production } \\
\text { Getting subsidies }\end{array}$ & 0 & 0.00 & 1 & 1.85 & 0 & 0.00 & 4 & 7.41 & 49 & 90.74 & 4.87 \\
$\begin{array}{c}\text { Existence of control at } \\
\text { every stage }\end{array}$ & 0 & 0.00 & 0 & 0.00 & 5 & 9.26 & 20 & 37.04 & 29 & 53.70 & 4.44 \\
$\begin{array}{c}\text { Greater marketing } \\
\text { opportunities }\end{array}$ & 1 & 1.85 & 6 & 11.11 & 25 & 46.30 & 15 & 27.78 & 7 & 12.96 & 3.39 \\
$\begin{array}{c}\text { Higher product prices } \\
\text { Innovativeness }\end{array}$ & 1 & 1.85 & 21 & 38.89 & 24 & 44.44 & 7 & 12.96 & 1 & 1.85 & 2.74 \\
\hline
\end{tabular}


When the ways through which the farmers engaged in organic production market their products were examined, it was found that $77.78 \%$ of the farmers market their products through wholesalers while $22.22 \%$ market their products in local markets.

Among the problems encountered by the farmers while performing organic production, first place is taken by lack of consciousness on the part of consumers with $35.19 \%$. On the other hand, $7.40 \%$ of the farmers were found to have no problem in organic production (Table 3).

Table 3. Problems encountered while performing organic production

\begin{tabular}{c|c|c}
\hline & $\mathbf{n}$ & $\mathbf{\%}$ \\
\hline Low yield & 15 & 27.78 \\
High costs & 15 & 27.78 \\
Lack of consciousness on the part of consumers & 19 & 35.19 \\
All & 1 & 1.85 \\
No problem & 4 & 7.40 \\
Total & 54 & 100.00 \\
\hline
\end{tabular}

It was found that according to the producers, the most important characteristics differentiating organic farming from conventional farming are producing quality food $(44.44 \%)$ and protecting nature $(44.44 \%)$ (Table 4$)$.

Table 4. Characteristics differentiating organic farming from conventional farming

\begin{tabular}{c|c|c}
\hline & $\mathbf{n}$ & $\mathbf{\%}$ \\
\hline Guarantee for purchasing due to contracted production & 4 & 7.42 \\
Quality food production & 24 & 44.44 \\
Protecting nature & 24 & 44.44 \\
Having high profits & 2 & 3.70 \\
Total & 54 & 100.00 \\
\hline
\end{tabular}

It was found that all the farmers participate in meetings, trainings and seminars organized in their villages and find these training activities useful.

All of the participating farmers were found to be willing for going on with organic farming in the future. A high majority of the farmers (77.78\%) were found to want to go on with organic farming as healthy products are created through organic farming. The percentage of the farmers wanting to go on with organic farming as it does not harm nature was found to be 9.25 (Table 5).

Table 5. The reasons for the farmers' going on with organic farming

\begin{tabular}{c|c|c}
\hline & n & \% \\
\hline More subsidies & 1 & 1.85 \\
No harm to nature & 5 & 9.25 \\
No pesticides & 3 & 5.56 \\
Quality food & 3 & 5.56 \\
Healthy products & 42 & 77.78 \\
Total & 54 & 100.00 \\
\hline
\end{tabular}


It was found that the information most needed by the farmers about organic farming is technical information. Other subjects for which the farmers need information are subsides, legal regulations and prices (Table 6).

Table 6. Subjects for which the farmers need information in relation to organic production

\begin{tabular}{c|c|c|c|c|c|c|c|c|c|c|c}
\hline \multirow{2}{*}{} & \multicolumn{2}{|c|}{ None } & \multicolumn{2}{c|}{ Little } & \multicolumn{2}{c|}{ Some } & \multicolumn{2}{c|}{ Much } & \multicolumn{2}{c|}{ Very much } & $\begin{array}{c}\text { Scale } \\
\text { mean }\end{array}$ \\
\cline { 2 - 14 } & $\mathbf{n}$ & $\mathbf{\%}$ & $\mathbf{n}$ & $\mathbf{\%}$ & $\mathbf{n}$ & $\mathbf{\%}$ & $\mathbf{n}$ & $\mathbf{\%}$ & $\mathbf{n}$ & $\mathbf{\%}$ & \\
\hline Technical information & 0 & 0.0 & 10 & 18.52 & 12 & 22.22 & 11 & 20.37 & 21 & 38.89 & 3.80 \\
Legal regulations & 5 & 9.26 & 22 & 40.74 & 25 & 46.30 & 2 & 3.70 & 0 & 0.00 & 2.44 \\
Price & 4 & 7.41 & 33 & 61.11 & 14 & 25.93 & 3 & 5.56 & 0 & 0.0 & 2.30 \\
Subsidies & 1 & 1.85 & 17 & 31.48 & 26 & 48.15 & 5 & 9.26 & 5 & 9.26 & 2.93 \\
\hline
\end{tabular}

\section{Discussion}

In the current study conducted to determine the factors affecting the adoption of organic farming in Samsun province, it was found that the most effective factors are health factors. That is, the farmers stated that due to the negative effects of chemical inputs used in conventional production on human health, they turned to organic farming. Similarly, Karki et al. (2011) found that health awareness and environmental awareness affected the decision of farmers to switch to organic farming. In a study conducted by Çukur and Işin (2008), it was found that the economic aspect of agriculture is very important for farmers, the ecological aspect of agriculture is important and the social aspect of agriculture is relatively less important. Rezvanfar et al. (2011) determined that there were many factors affecting the adoption of organic farming by farmers, including the socio-economic characteristics of farmers, the characteristics of enterprises, the information sources of farmers, the membership of farmers to farmer associations and the attitudes of farmers. Ceylan et al. (2010) found that economic and environmental factors were effective in farmers' adoption of organic farming. In a study conducted by Meda et al. (2018) in Burkina Faso, it was found that fertilizer support and the use of credit for grain production facilitated farmers' adoption of organic cotton production. Crawford et al. (2015) found that the communication network between farmers is very useful for the farmers engaged in organic farming. In the study conducted by Azam and Shaheen (2019), it was determined that there are 5 important factors in the adoption of organic farming. These factors were identified as economic, social, marketing, tillage and government policy.

It was determined that the majority of the farmers started organic production immediately after hearing of the concept of organic farming and had been in the business of organic farming at least for five years. Burton et al. (2003) also found in the first 5 years, the rate of adoption of organic farming is high. In a study conducted by Kallas et al. (2009), it was found that farmers who like to take risks, who care about the environment and who create employment in their businesses adopt organic farming in a shorter time. In a study conducted by Issa and Hamm (2017) with fresh vegetable and fruit producers, it was determined that farmers have positive views on organic farming and intend to switch to organic farming within 5 years.

A significant proportion of farmers think that their starting organic farming has no notable effect on their income. Artukoglu et al. (2009) determined that the income level of the farmers did not have an effect on their decisions to adopt organic farming. 
In the current study, it was found that according to the producers, the most important characteristics differentiating organic farming from conventional farming are producing quality food and protecting nature. In the current study, it was found that the meetings, trainings and seminars organized in villages about organic farming were found to be beneficial by the producers. Sodjinou et al. (2015) found that communication with agricultural extension services facilitated the adoption of organic farming by farmers. The research conducted by Adebayo and Oladele (2013) has revealed a positive relationship between the frequency of communication with extentionists and the adoption of organic farming by farmers.

In the current research, it was determined that all of the farmers wanted to continue their organic production in the future. In a study conducted by Çukur (2015) however it was determined that farmers do not want to continue organic production in the future as they do not have sufficient knowledge about organic farming.

\section{Conclusion}

It was determined that all of the farmers interviewed in the study wanted to continue their organic production in the future and their aim was to cultivate healthy products. This is important for the sustainability of organic farming. Agricultural extension and training programs should be implemented for the adoption of organic farming by more farmers in the district. For this purpose, it is necessary to identify the regions that are suitable for organic farming in the district and where the use of chemical inputs is very low and works should be conducted for farmers to adopt organic farming.

In the current research, it was determined that farmers need technical knowledge about organic farming and they also need information about subsidies, legal regulations and prices. Therefore, a comprehensive extension program should be prepared and put into practice to provide farmers with extension and consultancy services.

In the current study, it was determined that most of the farmers did not keep their business records. Business records are an important source of data for farmers to make the right decision. Therefore, farmers should be informed about the importance of keeping business records.

Consumers should be informed about the importance of the products of organic farming for health and their awareness about organic farming should be increased. The number of organic markets should be increased to make it easier for consumers to access organic products.

Organic farming is very important for sustainable agriculture. The increase in organic farming subsidies is thought to be effective in the adoption of organic farming by more farmers.

Determination of the factors that affect farmers' adoption of organic agriculture seems to be important in terms of using it as data for the development of policies related to organic farming.

\section{REFERENCES}

[1] Adebayo, S. A., Oladele, O. I. (2013): Vegetable farmers' attitude towards organic agriculture practices in South Western Nigeria. - Journal of Food, Agriculture \& Environment 11(2): 548-552. 
[2] Aksoy, U. (2002): Turkey. - In: Al Bitar, L. (ed.) Report on Organic Agriculture in the Mediterranean Area. CIHEAM, Bari, pp.147-159.

[3] Aksoy, U., Altındişli, A. (1999): Ecological Agricultural Products in the World and Turkey Production, Export and Development Facilities. - İstanbul Chamber of Commerce Publication No 1999-70, İstanbul (in Turkish).

[4] Altındişli, A., Aksoy, U. (2010): Status of organic agriculture in the world and Turkey. Turkey Agricultural Engineering VII. Technical Congress, Ankara, pp. 213-227 (in Turkish).

[5] Anonymous (2019a): Statistics. - https://www.tarimorman.gov.tr/Konular/BitkiselUretim/Organik-Tarim/Istatistikler.

[6] Anonymous (2019b): Map of Samsun's districts. - http://www.istanbulrehber.com/harita/il/samsun-haritasi.asp.

[7] Artukoglu, M. M., Tarkan, E., Gencler, F., Miran, B. (2009): Evaluating the factors of transition in organic cotton production for farmers: case of Salihli, Turkey. - Bulg. J. Agric. Sci. 15: 77-83.

[8] Azam, M. S., Shaheen, M. (2019): Decisional factors driving farmers to adopt organic farming in India: a cross-sectional study. - International Journal of Social Economics 46(4): 562-580.

[9] Burton, M., Rigby, D., Young, T. (2003): Modelling the adoption of organic horticultural technology in the UK using Duration Analysis. - The Australian Journal of Agricultural and Resource Economics 47(1): 29-54.

[10] Ceylan, İ. C., Olhan, E., Köksal, Ö. (2010): Determination of the effective factors on organic olive cultivation decision. - African Journal of Agricultural Research 5(23): 3164-3168.

[11] Crawford, C., Grossman, J., Warren, S. T., Cubbage, F.(2015): Grower communication networks: Information sources for organic farmers. - Journal of Extension 53(3).

[12] Çukur, T., Işın, F. (2008): Industrial tomato farmers view of multifunctionality of agriculture concept in Torbalı district of İzmir. - Ege Journal of Agricultural Research 45(3): 185-193 (in Turkish).

[13] Çukur, T. (2015): Conventional dairy farmers converting to organic dairy production in Turkey. - Polish Journal of Environmental Studies 24(4): 1543-1551.

[14] Demiryürek, K. (2011): The concept of organic agriculture and current status of in the world and Turkey. - Journal of Agricultural Faculty of Gaziosmanpasa University 28(1): 27-36 (in Turkish).

[15] Issa, I., Hamm, U. (2017): Adoption of organic farming as an opportunity for Syrian farmers of fresh fruit and vegetables: an application of the theory of planned behaviour and structural equation modelling. - Sustainability 9: 1-22.

[16] Kallas, Z., Serra, T., Gil, J. M. (2009): Farmer's objectives as determinant factors of organic farming adoption. - 113th EAAE Seminar "A resilient European Food Industry and Food Chain in a Challenging World", Chania, Crete, Greece.

[17] Karki, L., Schleenbecker, R., Hamm, U. (2011): Factors influencing a conversion to organic farming in Nepalese tea farms. - Journal of Agriculture and Rural Development in the Tropics and Subtropics 112(2): 113-123.

[18] Meda, Y. J. M., Egyir, I. S., Zahonogo, P., Donsaananang, J., Atewamba, C. (2018): Institutional factors and farmers' adoption of conventional, organic and genetically modified cotton in Burkina Faso. - International Journal of Agricultural Sustainability 16(1): 40-53.

[19] Rezvanfar, A., Eraktan, G., Olhan, E. (2011): Determine of factors associated with the adoption of organic agriculture among small farmers in Iran. - African Journal of Agricultural Research 6(13): 2950-2956.

[20] Sodjinou, E., Glin, L. C., Nicolay, G., Tovignan, S., Hinvi, J. (2015): Socio economic determinants of organic cotton adoption in Benin, West Africa. - Agricultural and Food Economics 3(12): 1-22. 